\title{
Monitoring Building Systems for Schedule Compliance
}

AM Jensen

ST Belew

February 2013

Pacific Northwest

NATIONAL LABORATORY

Proudly Operated by Battelle Since 1965 


\title{
DISCLAIMER
}

This report was prepared as an account of work sponsored by an agency of the United States Government. Neither the United States Government nor any agency thereof, nor Battelle Memorial Institute, nor any of their employees, makes any warranty, express or implied, or assumes any legal liability or responsibility for the accuracy, completeness, or usefulness of any information, apparatus, product, or process disclosed, or represents that its use would not infringe privately owned rights. Reference herein to any specific commercial product, process, or service by trade name, trademark, manufacturer, or otherwise does not necessarily constitute or imply its endorsement, recommendation, or favoring by the United States Government or any agency thereof, or Battelle Memorial Institute. The views and opinions of authors expressed herein do not necessarily state or reflect those of the United States Government or any agency thereof.

\author{
PACIFIC NORTHWEST NATIONAL LABORATORY \\ operated by \\ BATTELLE \\ for the \\ UNITED STATES DEPARTMENT OF ENERGY \\ under Contract DE-AC05-76RLO1830
}

Printed in the United States of America

Available to DOE and DOE contractors from the

Office of Scientific and Technical Information.

P.O. Box 62, Oak Ridge, TN 37831-0062;

ph: (865) 576-8401

fax: (865) 576-5728

email: reports $a$ adonis.osti.gov

\author{
Available to the public from the National Technical Information Service, \\ U.S. Department of Commerce, 5285 Port Royal Rd., Springfield, VA 22161 \\ ph: (800) 553-6847 \\ fax: (703) 605-6900 \\ email: orders a ntis.fedworld.gov \\ online ordering: http://www.ntis,gov/ordering.htm
}

This document was printed on recycled paper. 


\section{Monitoring Building Systems for Schedule Compliance}

AM Jensen

ST Belew

February 2013

Prepared for

the U.S. Department of Energy

under Contract DE-AC05-76RL01830

Pacific Northwest National Laboratory

Richland, Washington 99352 


\section{Summary}

As Pacific Northwest National Laboratory (PNNL) initiated a Core Business Hours program, it became a challenge to ensure that the hundreds of systems campus wide were operating within their programmed schedules. Therefore, a collaborative exchange between PNNL operations and PNNL researchers developing the Decision Support for Operations and Maintenance (DSOM) software package was initiated to create a tool to solve this problem.

This new DSOM tool verifies systems are operating within scheduled operation times by polling Building Automation and Control Network (BACnet) identifiers of systems' on/off or command statuses. The tool records the time spent in operation state (ON) and totalizes each system over a rolling 7-day period, highlighting systems that are running over the scheduled hours. This snapshot view allows building management to look quickly at the entire campus to ensure that systems are not operating beyond their scheduled hours. 


\section{Acronyms and Abbreviations}

BACnet

BAS

$\mathrm{CBH}$

DSOM

HVAC

OFF

ON

PNNL
Building Automation and Control Network

Building Automation System

Core Business Hours (Tool)

Decision Support for Operations and Maintenance

Heating, Ventilation, and Air Conditioning

non-operative state

operation state

Pacific Northwest National Laboratory 


\section{Contents}

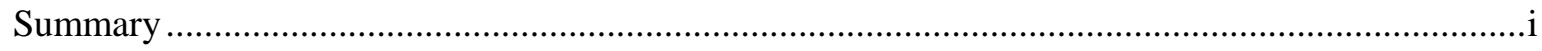

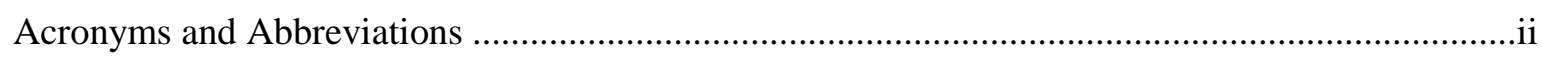

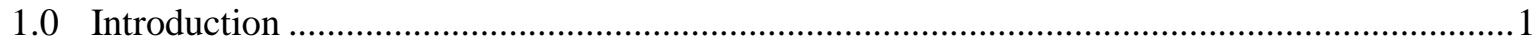

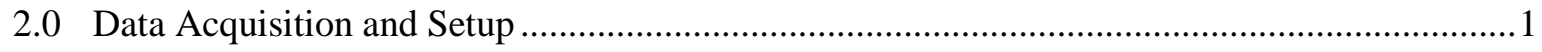

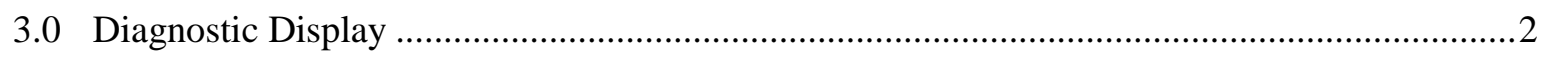

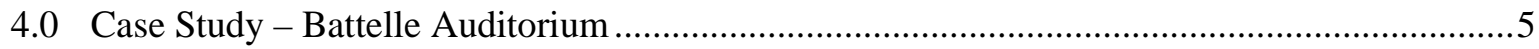

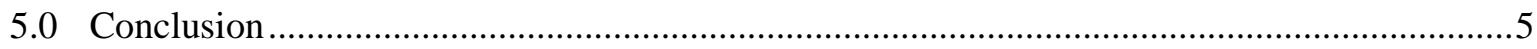

\section{Figures}

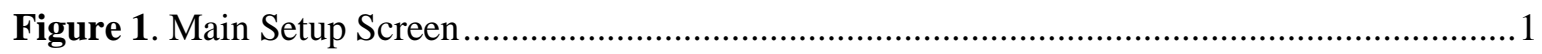

Figure 2. Hierarchy Breakdown: Area, Building, and System Trees............................................2

Figure 3. System Controller, Identifier, and Administrative Occupied Schedule Programming.......2

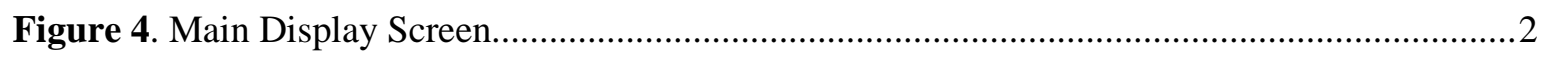

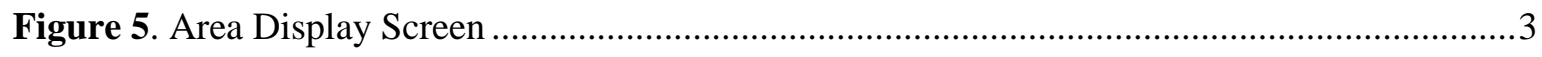

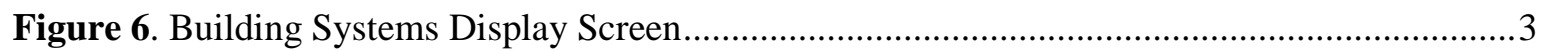

Figure 7. Heat Pump Operation Trend ................................................................................. 


\subsection{Introduction}

The Core Business Hours (CBH) Tool was developed to create a top-level dashboard view of all the systems for each building on the campus. Equipment such as fans, pumps, and air compressors with two operational states in the building automation system (BAS) can be monitored by the Tool: State 0 indicates the non-operative state (OFF), and State 1 indicates ON.

The chief function of the CBH Tool is to totalize run hours for all equipment programmed into it to monitor and verify equipment operation. The layout and graphical interface displays the amount of time a system has operated over a rolling 7-day period and alerts the viewer if a system has exceeded its scheduled time. The Tool also provides building management a means to assess all systems for problems quickly rather than spending hours sifting through trends and schedules saved by the BAS.

\subsection{Data Acquisition and Setup}

To program the CBH Tool, an inventory list of all systems (fans/pumps/air compressors) in each building was created. The list includes the actual data point for each system (the equipment's point name in the BAS) as well as the main controller, local sub-controller, and most importantly the BACnet identifier. Using an equipment's on/off status is preferred, as a command status may not indicate the actual operational status (i.e., a command status may be ON, but the equipment could be disconnected or otherwise switched off). If this is not available, the command status may be used, but this should be noted.

In the tool's setup screen (Figure 1), the campus is divided into a hierarchy by area, building, and system (Figure 2). Areas, buildings, or systems can be added and edited as necessary. Once selected, an individual system can then be edited. The controller name and data point type are selected, the BACnet ID number is input, and the schedule and allowable overrun hours configured (Figure 3). By default, PNNL's core business hours schedule is automatically configured (0600-1800 hours Monday through Friday), with 5 hours of allowable error (overrun). The schedule can be configured manually or set to the hourly range choices of 0600-1800, 0700-1700, or 24/7 with the "Set" buttons below the schedule (Figure 3).

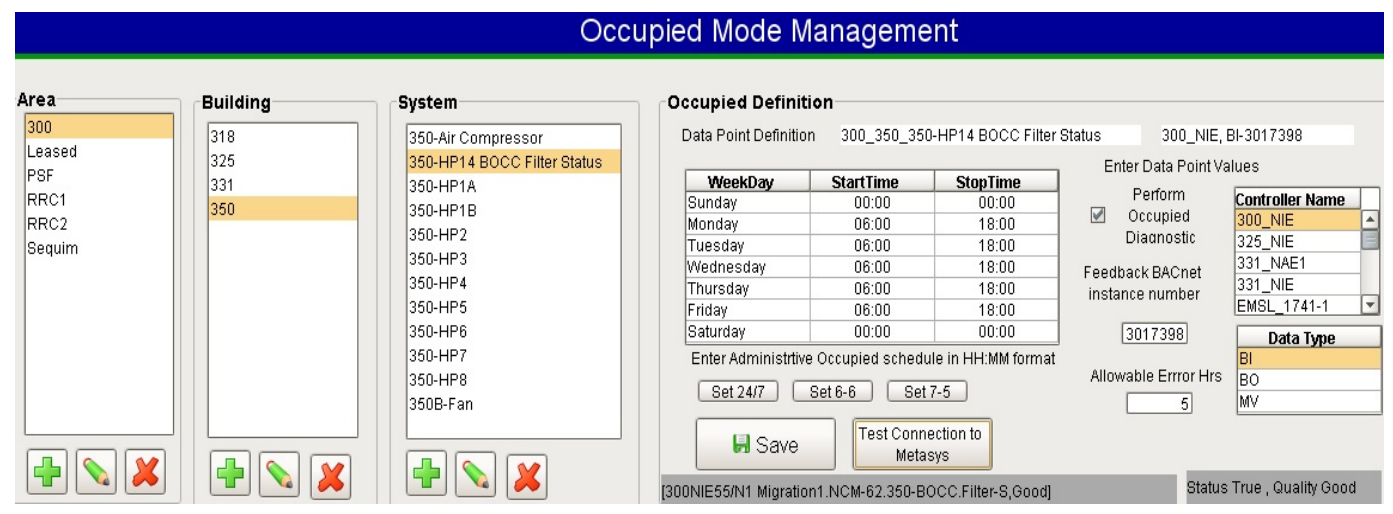

Figure 1. Main Setup Screen 


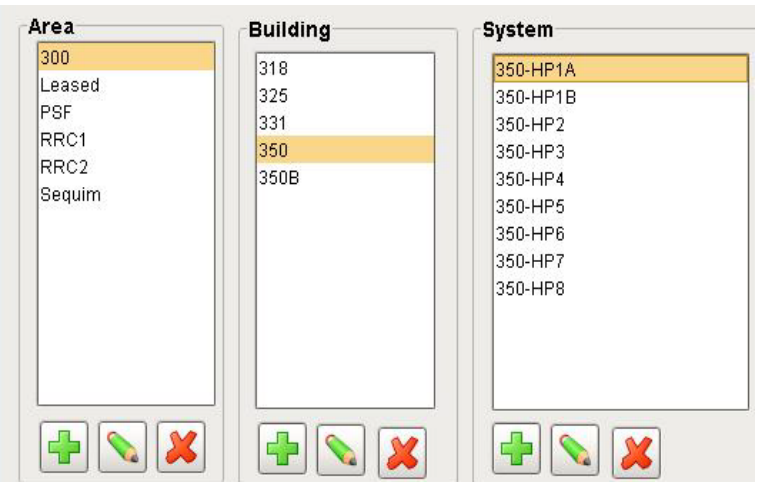

Figure 3. Hierarchy Breakdown: Area, Building, and System Trees

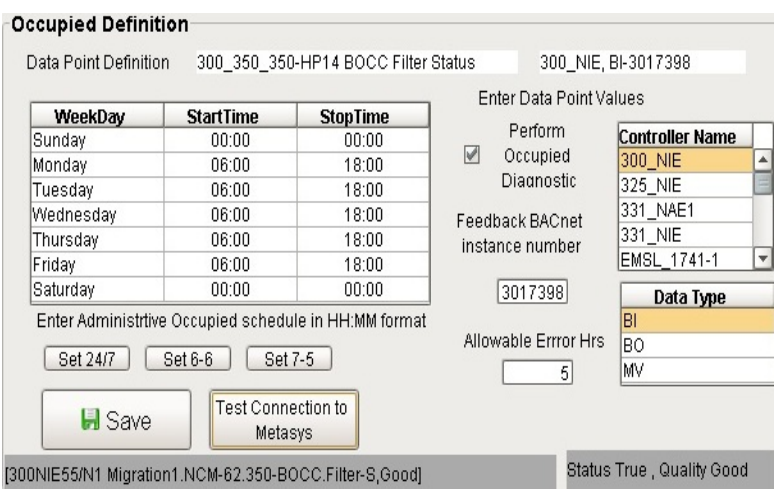

Figure 2. System Controller, Identifier, and Administrative Occupied Schedule Programming

Once a piece of equipment is programmed into the Tool, clicking the "Test Connection to Metasys" button will enable connection with Metasys (PNNL's BAS) and display the name of the point, the current run status of the item, and the quality of the connection. This ensures that the correct BACnet instance number was input and the correct controller and data type selected.

\subsection{Diagnostic Display}

The main display window shows two sections (Figure 4). In the left-hand side box, each building is listed under its respective area (Figure 5). The right hand side of the screen contains a box that shows the systems of the selected building, the scheduled hours, actual run hours, hours over, and the allowable error for each system (Figure 6).

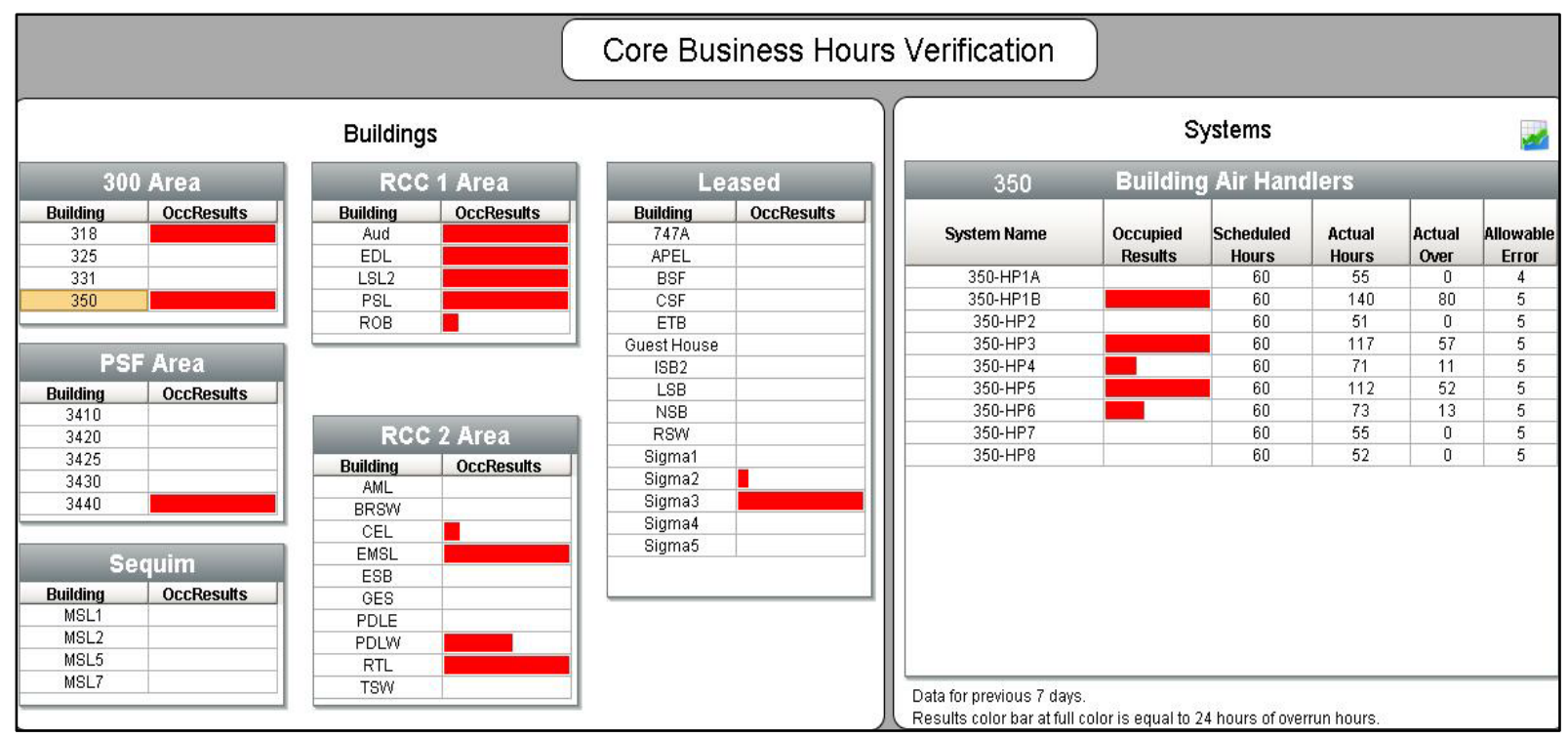

Figure 4. Main Display Screen 


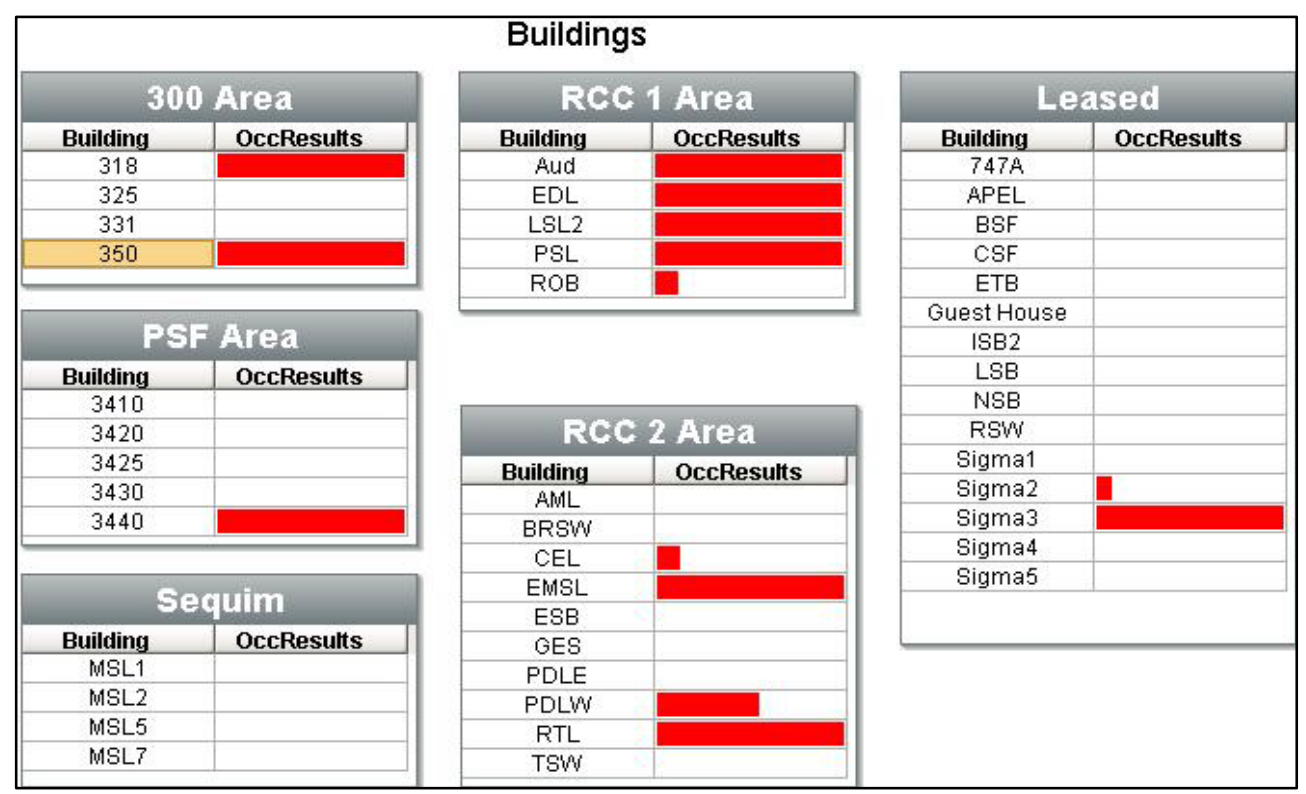

Figure 5. Area Display Screen

\begin{tabular}{|c|c|c|c|c|c|}
\hline \multicolumn{5}{|c|}{ Systems } & \multirow{2}{*}{ inf } \\
\hline \multicolumn{5}{|c|}{ Buflding sir Handlers } & \\
\hline System Name & $\begin{array}{c}\text { Occupied } \\
\text { Results }\end{array}$ & $\begin{array}{c}\text { Scheduled } \\
\text { Hours }\end{array}$ & $\begin{array}{l}\text { Actual } \\
\text { Hours }\end{array}$ & $\begin{array}{l}\text { Actual } \\
\text { Over }\end{array}$ & $\begin{array}{c}\text { Allowable } \\
\text { Error }\end{array}$ \\
\hline 350-HP1A & & 60 & 55 & 0 & 4 \\
\hline 350-HP1B & & 60 & 140 & 80 & 5 \\
\hline $350-\mathrm{HP} 2$ & & 60 & 51 & 0 & 5 \\
\hline $350-\mathrm{HP} 3$ & & 60 & 117 & 57 & 5 \\
\hline $350-\mathrm{HP}_{4}$ & & 60 & 71 & 11 & 5 \\
\hline $350-H P 5$ & & 60 & 112 & 52 & 5 \\
\hline 350-HP6 & & 60 & 73 & 13 & 5 \\
\hline 350-HP7 & & 60 & 55 & 0 & 5 \\
\hline 350-HP8 & & 60 & 52 & 0 & 5 \\
\hline
\end{tabular}

Figure 6. Building Systems Display Screen

To view the systems of a building, the building of interest is clicked, which will change the content of the Systems box to that building on the Main display screen.

In each area's box, there is an open cell adjacent to each building under the "OccResults" heading. When one or more systems in that building exceed the actual hours by more than the allowable error, a red bar begins to populate. The size of this bar is proportional to the number of hours overrun, with a full bar indicating at least 24 hours of total overrun time. 
When a specific building is selected, overages are displayed under the “Occupied Results” heading, which is the same as under the building list. This allows positive, rapid identification of the system(s) overrunning so that they can be immediately and effectively addressed. In addition, the scheduled hours can be verified as well as the actual run time and the number of hours each system has overrun. A full red bar indicates that the system in question has run at least 24 hours beyond its scheduled time, plus allowable error.

To investigate and trend on/off time, a trend chart is available. When a particular building is selected and its systems displayed, the user can click a small chart icon in the upper right hand corner (Figure 6). This will display a trend chart for each system in the selected building. This trend chart can be used to investigate the reason for overrun; e.g., overrides, early starts or night-time setback starts from low/high temperatures, excessive cycling, and operating on weekends or holidays due to poor scheduling control. The trend chart can be adjusted to compare systems simultaneously and change the date range of trends with ease.

Figure 7 shows one such trend for a heat pump in one of PNNL's buildings for Saturday, January 12, 2013. This heat pump serves a carpenter's workshop that is unoccupied on weekends. Comparison to the outdoor air recorded in the BAS shows temperatures in the 20s to low 30s in degrees Fahrenheit, a situation that could be driving the extra run time. Further investigation by the building engineer or a designee is recommended to determine the cause of the weekend operation.

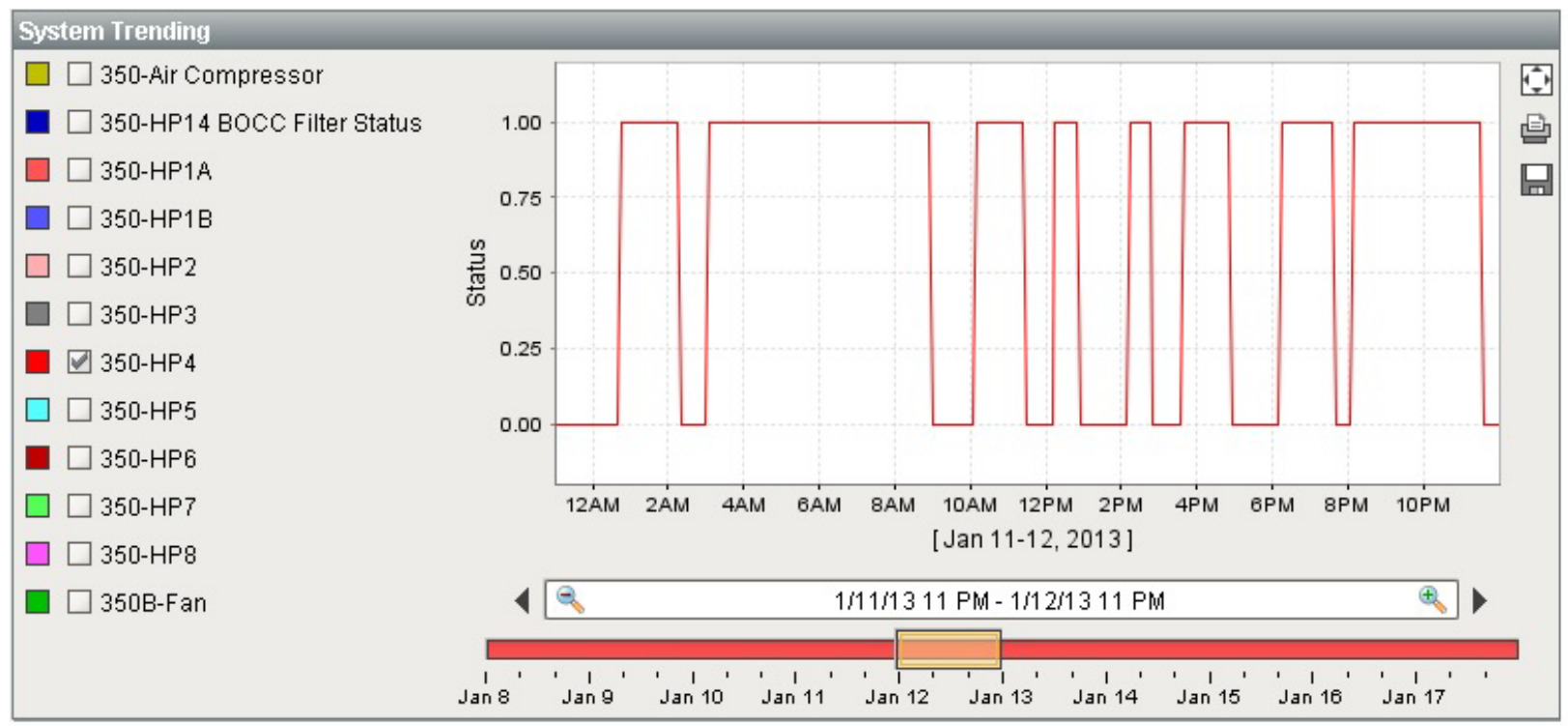

Figure 7. Heat Pump Operation Trend $(\mathrm{ON}=1 ; \mathrm{OFF}=0)$

This trending option can be quite useful. While the primary function of the $\mathrm{CBH}$ tool is to totalize equipment run hours and display those results in a meaningful way, its functionality allows for other uses. If trend history was not saved in the BAS, the CBH tool's trending option can be used as an effective replacement. Building management can also look at hour totalizations and trend data to determine if a piece of equipment is not operating when it should be. 


\subsection{Case Study - Battelle Auditorium}

Implementation of the $\mathrm{CBH}$ tool has demonstrated the value by quick identification of poor schedule control. One such instance occurred with the Battelle Auditorium, a typical stage and seating facility used for PNNL and community events such as conferences, concerts, and film screenings. Use of the auditorium is scheduled via a Microsoft Outlook calendar, and the building's HVAC system control is tied into this calendar.

After the Auditorium was added to the CBH Tool and several days elapsed, it was noted that the auditorium supply fan was running approximately 130 hours per week or an average of more than 18 hours per day, even though it was scheduled as occupied for only about 30 hours per week in Outlook. This was diagnosed as an indication of a problem, and further investigation was performed. It was determined that the Auditorium systems were not responding to the Outlook schedule; additionally, the low and high setback band was too narrow. The connection with Outlook was repaired, and the setback band widened. These changes reduced the weekly runtime to 20-30 hours.

\subsection{Conclusion}

With the federal mandates for significant energy reduction goals, it has never been so important to abate energy waste. Building engineers and managers are often busy, but providing them with an effective tool to examine the facilities under their charge ensures that they are able to monitor the facility's systems and implement prompt, effective energy-saving changes.

A typical BAS display allows the user to view the current operating state of a piece of equipment and shows a historical trend of that data. While some conclusions can be inferred from this sort of trend, it is time consuming to locate every system in a building and manually totalize its hours of operation to ensure good system control. However, the "bird's-eye view” provided by DSOM’s CBH Tool solves this problem in a simple, clear, and effective manner. 


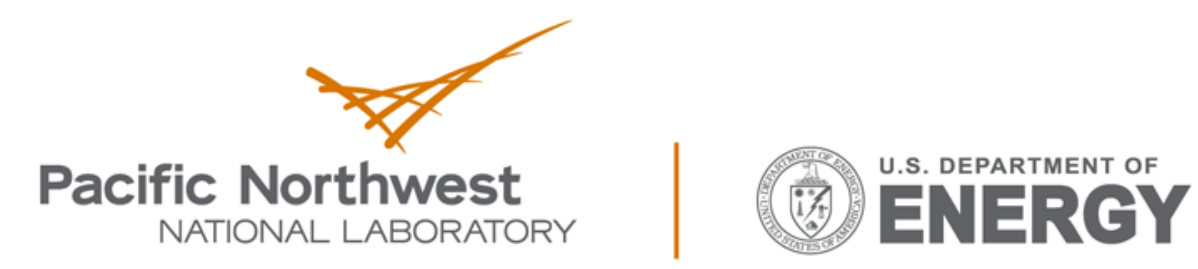

Proudly Operated by Battelle Since 1965

902 Battelle Boulevard

P.O. Box 999

Richland, WA 99352

1-888-375-PNNL (7665)

www.pnnl.gov 